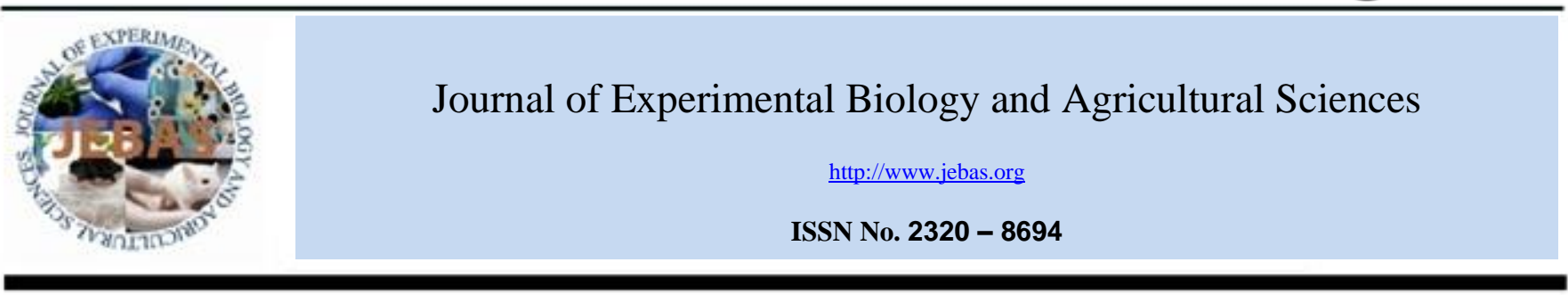

\title{
EFFECT OF BIOLOGICAL FERTILIZER ON THE GROWTH AND NODULES FORMATION TO SOYA BEAN (Glicine max (L.) MERRILL) IN ULTISOL UNDER NET HOUSE CONDITIONS
}

\author{
Sarawa $^{1, *}$, Halim $^{2}$ and Makmur Jaya Arma ${ }^{2}$ \\ ${ }^{1}$ Specifications Agronomy, Department of Agrotechnology, Faculty of Agriculture, Halu Oleo University, Southeast Sulawesi, Indonesia \\ ${ }^{2}$ Specifications Weed Science, Department of Agrotechnology, Faculty of Agriculture, Halu Oleo University, Southeast Sulawesi, Indonesia
}

Received - June 06, 2016; Revision - August 13, 2016; Accepted - October 19, 2016

Available Online - November 13, 2016

DOI: http://dx.doi.org/10.18006/2016.4(Issue6).617.624

\section{KEYWORDS}

Nodule

Soybean

Bio-fertilizer

Nodule formation

Ultisol

ABSTRACT

Present study was aim to assess the effect of various concentrations of biological fertilizers on the growth and nodules formation in soybean crop (Glicine max (L.) Merrill) in Ultisol under net house condition. Study was conducted under net house condition in the month of July to October 2014. Study was conducted in randomized block design (RBD) with six treatments and each treatment was replicated with 3 replications. The variables studied were plant height, stem diameter, root length, nodule diameter, nodule number, effective nodules number, fresh nodule weight, wet effective nodules weight, dry nodule weight and dry effective nodule weight. Results of study revealed that treatments of M-bio fertilizer at concentration of $12 \mathrm{ml}$ per liter of water provide the highest growth such plant height as $44.65 \mathrm{~cm}$, stem diameter as $0.86 \mathrm{~cm}$ and roots length as $24.49 \mathrm{~cm}$. The treated soybean plant have 21.27 nodules and among these number of effective nodules are 16.63 pieces.
\end{abstract}

* Corresponding author

E-mail: sarawa60@yahoo.com (Sarawa Mamma)

Peer review under responsibility of Journal of Experimental Biology and Agricultural Sciences.

Production and Hosting by Horizon Publisher India [HPI] (http://www.horizonpublisherindia.in/).

All rights reserved.
All the article published by Journal of Experimental Biology and Agricultural Sciences is licensed under a Creative Commons Attribution-NonCommercial 4.0 International License Based on a work at www.jebas.org.

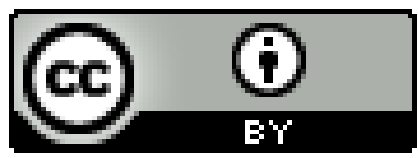




\section{Introduction}

Soybean is leguminous crops which have ability to fix atmospheric nitrogen. According to Sanginga et al. (2010) this plant can fix annually $11-120 \mathrm{~kg}$ atmospheric nitrogen in the form of Nitrate. Further, Handarson et al. (1989) reported that nitrogen fixation ability of the soybean crop is influenced by several factors such as plant varieties, soil types, climatic conditions, crop management practices, availability of organic matter (Kundu et al., 1996) and the availability of Phosphorus and Sulfur (Kris Joko, 2001; Singh, 2004).

According to Sarawa (2014) response of soybean crop toward biological nitrogen fixation (soybean- rhizobium symbiosis) are more prominent than the other nitrogen fertilizers. The possible explanation of this may be quick absorption and rapid utilization of biologically fix nitrogen as compare to other nitrogen fertilizers. Further it was reported that the excess use of inorganic nitrogen fertilizers not only inhibit the rate of biological nitrogen fixation but also inhibit the formation of nodules. Further it was reported that this excess use of chemical fertilizers also lead to increase soil acidity by releasing hydrogen ions in applied soil.

On the other hand use of rhizobium based bio-fertilizer would be hampered because it is very sensitive to soil acidity (Anetor \& Akinrinde, 2006). Further, addition of small amounts of inorganic $\mathrm{N}$ fertilizer is not only spurs the growth of soybean plant but also increase the legumes nitrogen fixation (Keyser \& $\mathrm{Li}$, 1992; Bakere \& Hailemariam, 2012). Integrated management of land, crop, organic and inorganic fertilizer along with microbial community is very important for sustainable agriculture under acidic soil conditions. These practices not only increase soil health and biodiversity but also has positive influence crop yield (Bejiga, 2004; Ellafi et al., 2011).

Soil acidity caused shortage of nitrogen, which lead to cause deficiency of calcium (Ca) and phosphorus $(\mathrm{P})$, which in turn inhibits the growth and rhizobium infection on plant roots (Barbara \& Ndakidemi, 2010). Some bio-activators such as biological fertilizer can enhance the activity of rhizobium in the soil. These biological fertilizers not only help in nitrogenfixation but also help in aggregate phosphate stabilizing. In Sulawesi, Indonesian farmer used commercial bio-fertilizer Mbio fertilizers for increasing the biological nitrogen fixation by rhizobium and increasing crop production. M-bio is a microbial fertilizer that is mixed cultures of beneficial microbes which consist of nitrogen-fixing microbes, produce enzymes and hormones (Nurmayulis et al., 2014). Present study was conducted to explore the effect of M-bio fertilizers on rhizobium nitrogen fixation and nodule formation under Ultisol soil condition.

\section{Materials and Methods}

\subsection{Study Area and Experimental Setup}

Present study was conducted (from July to October 2014) under net house conditions. Experimental area is located in Anduonohu Village, District Poasia, Kendari City and Province of Southeast Sulawesi, Indonesia. Plant were grown in polybag $(30 \mathrm{~cm} \times 40 \mathrm{~cm})$ containing $10 \mathrm{~kg}$ Ultisol soil and study was conducted in randomized block design (RBD) with six treatments i.e. without M-bio (control), M-bio $3 \mathrm{ml}$ per liter of water, M-bio $6 \mathrm{ml}$ per liter of water, M-bio $9 \mathrm{ml}$ per liter of water, M-bio $12 \mathrm{ml}$ per liter and $15 \mathrm{ml} \mathrm{M}$-bio per liter of water, each treatment was replicated with 3 replications.

\subsection{Preparation of Planting Media}

The soil has been collected from the study area at layer of top soil $(0-30 \mathrm{~cm})$; collected soil samples were taken into the laboratory and debris such as twigs, roots, leaves and small rocks particles were removed from these samples. Cleared soil was shifted into a polybag with a weight of $10 \mathrm{~kg}$ soil. These soil containing polybags were filled with water until it reached the capacity of field and it was followed by the incubation, for 2 days under net house. The soybean seed soak for 10 minutes in various concentrations of M-Bio solution were used as a treatment. Seeds were planted @ 3 seeds per polybag and after the age of 10 days, only two plants per poly bag were maintained till the completion of study 50 days after plantation (DAP), randomly three poly bags for each treatment were selected and plants of these poly bags were harvested and used to study various selected attributes.

Various attributes which were studied after harvesting (50 DAP) are plant height, stem diameter, root length, number of nodules, nodule diameter, number of effective nodules, fresh weight nodules, dry weight of nodules, fresh weight of effective nodules and dry weight of effective nodules. Effective nodules are those nodules which gave pink color after cutting through razor. Among these stem and nodule diameter was measured with the help of sigma (calipers) while the dry weight of nodules was calculated after drying nodules at $80^{\circ} \mathrm{C}$ for $48 \mathrm{hrs}$. Various nodule weights were calculated by using following formula.

Nodules Weight $=$ Weight of effective nodules + weight of non effective nodules

\section{Data Analysis}

Data of each variable were analyzed by variance of analysis. If the $\mathrm{F}$ count is greater than $\mathrm{F}$ table, than continued with Honestly Significant Difference Test (HSDT) at 95\% confidence level. To determine the effect of a dose of M-bio to the growth and formation of pimples, and then be made curve and display the regression equation and the value of $\mathrm{R}$. 
Table1. Effect of M-bio fertilizer to average of height plant, stem diameter and root length at the age of 50 DAP.

\begin{tabular}{lccc} 
Treatments & Plant height $(\mathrm{cm})$ & Stem diameter $(\mathrm{cm})$ & Roots length $(\mathrm{cm})$ \\
With out M-bio (control) & $23.41 \pm 0.247^{\mathrm{e}}$ & $0.33 \pm 0.006^{\mathrm{e}}$ & $11.01 \pm 0.580^{\mathrm{e}}$ \\
M-bio $3 \mathrm{ml}$ per liter of water & $28.53 \pm 0.302^{\mathrm{d}}$ & $0.46 \pm 0.006^{\mathrm{d}}$ & $15.52 \pm 0.490^{\mathrm{d}}$ \\
M-bio $6 \mathrm{ml}$ per liter of water & $32.04 \pm 0.560^{\mathrm{c}}$ & $0.63 \pm 0.009^{\mathrm{c}}$ & $17.34 \pm 0.360^{\mathrm{c}}$ \\
M-bio 9 ml per liter of water & $38.21 \pm 0.303^{\mathrm{b}}$ & $0.82 \pm 0.015^{\mathrm{a}}$ & $21.79 \pm 0.338^{\mathrm{b}}$ \\
M-bio $12 \mathrm{ml}$ per liter of water & $44.65 \pm 0.488^{\mathrm{a}}$ & $0.86 \pm 0.012^{\mathrm{a}}$ & $24.49 \pm 0.302^{\mathrm{a}}$ \\
M-bio 15 ml per liter of water & $37.59 \pm 0.072^{\mathrm{b}}$ & $0.74 \pm 0.019^{\mathrm{b}}$ & $17.90 \pm 0.401^{\mathrm{c}}$ \\
Average SEM Value & 0.42 & 0.54 & 0.43 \\
\hline HSDT 95\% & 3.23 & 0.08 & 1.39 \\
\hline
\end{tabular}

Here, DAP = day after planting, SEM = standard error mean, the number followed by the same superscript letters in the same column are not significantly differ on HSDT $95 \%$.

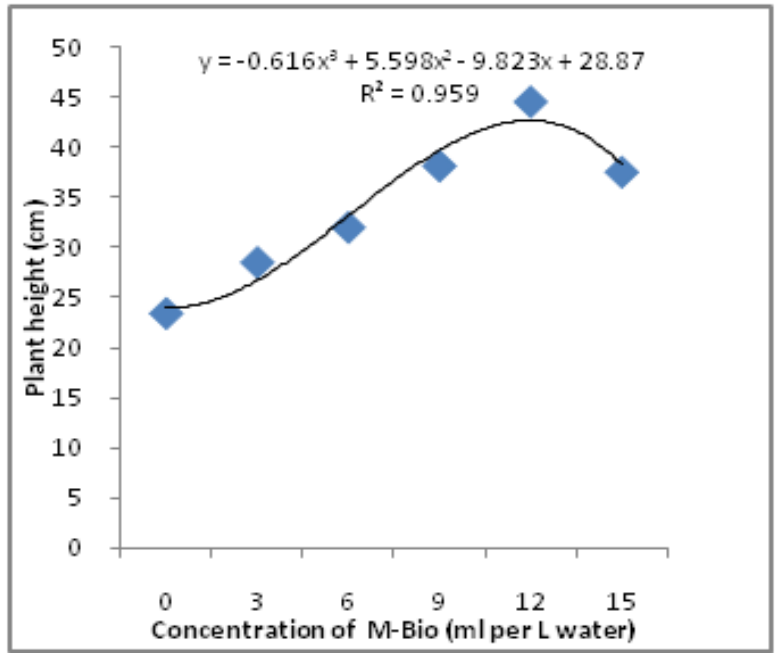

Figure 1 The concentration M-Bio relationship with plant height

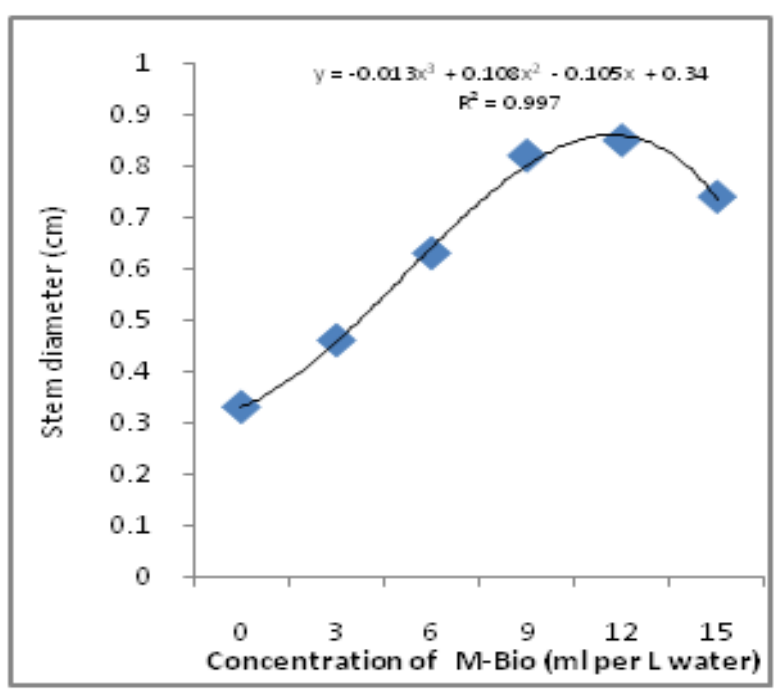

Figure 2 Theconcentration M-Bio relationship with stem diameter

\section{Results}

3.1 Effect of M-bio on various growth characteristics

Effect of M-bio fertilizer on average plant height, stem diameter and roots length are represented in table 1. Results of study revealed that application M-bio fertilizer had significant effect on plant of height, stem diameter and roots length of soybean plant.

Among the various tested treatments, the treatment containing $12 \mathrm{ml}$ per liter of M-bio provides a higher impact on plant height, stem diameter and root length. It is significantly different from other treatments, except in stem diameter where this treatment was not significantly differ than the $9 \mathrm{ml}$ per liter of M-bio. Further, the lowest effect was obtained in the control treatment for all the tested attributes.

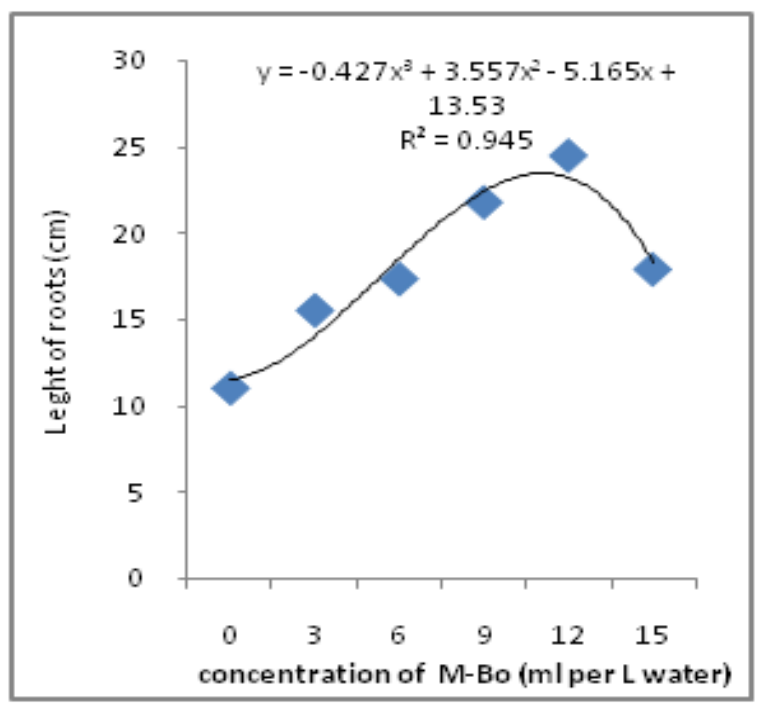

Figure 3 The concentration M-Bio relationship with length of roots 
Table 2 Effect of M-biofertilizer on average of nodule diameter, the number of nodules and the number of effective nodules.

\begin{tabular}{|lccc|} 
Treatments & $\begin{array}{c}\text { Nodule diameter } \\
(\mathrm{mm})\end{array}$ & $\begin{array}{c}\text { Number of nodules } \\
\text { (pieces) }\end{array}$ & $\begin{array}{c}\text { Number of effective nodules } \\
\text { (pieces) }\end{array}$ \\
\hline Without M-bio (control) & $1.03 \pm 0.012^{\mathrm{f}}$ & $6.63 \pm 0.406^{\mathrm{d}}$ & $2.57 \pm 0.145^{\mathrm{e}}$ \\
M-bio $3 \mathrm{ml}$ per liter of water & $1.93 \pm 0.026^{\mathrm{e}}$ & $10.27 \pm 0.338^{\mathrm{c}}$ & $5.80 \pm 0.153^{\mathrm{d}}$ \\
M-bio $6 \mathrm{ml}$ per liter of water & $2.86 \pm 0.045^{\mathrm{d}}$ & $12.43 \pm 0.536^{\mathrm{c}}$ & $10.17 \pm 0.410^{\mathrm{c}}$ \\
M-bio 9 ml per liter of water & $3.94 \pm 0.036^{\mathrm{c}}$ & $17.00 \pm 0.200^{\mathrm{b}}$ & $13.63 \pm 0.338^{\mathrm{b}}$ \\
M-bio 12 ml per liter of water & $5.14 \pm 0.025^{\mathrm{a}}$ & $21.27 \pm 0.484^{\mathrm{a}}$ & $16.63 \pm 0.384^{\mathrm{a}}$ \\
M-bio 15 ml per liter of water & $4.80 \pm 0.044^{\mathrm{b}}$ & $17.40 \pm 0.439^{\mathrm{b}}$ & $14.23 \pm 0.524^{\mathrm{b}}$ \\
Average SEM Value & 0.003 & 0.54 & 0.37 \\
\hline HSDT 95\% & 0.17 & 2.15 & 1.77 \\
\hline
\end{tabular}

Here, SEM = standard error mean, the number followed by he same superscript letters in the same column are not significantly differ on HSDT $95 \%$.

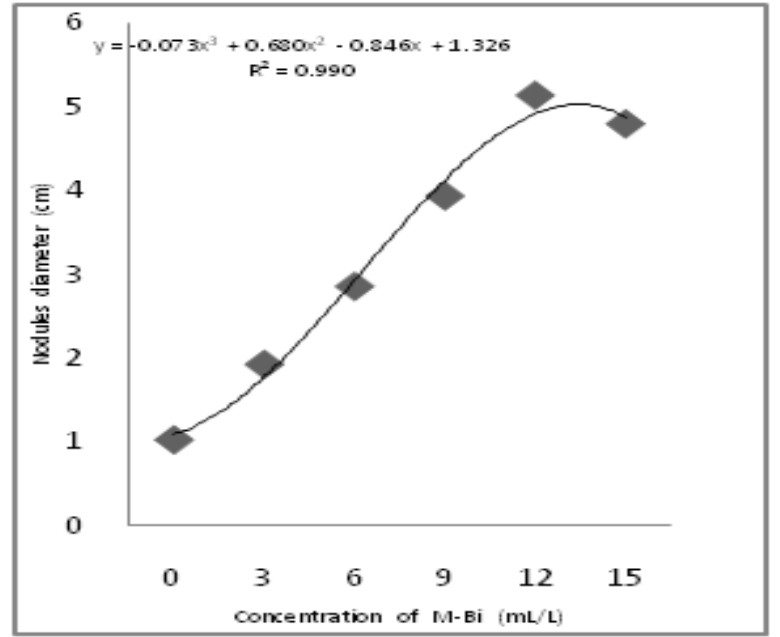

Figure 4 The concentration of M-Bio relationship with nodules diameter

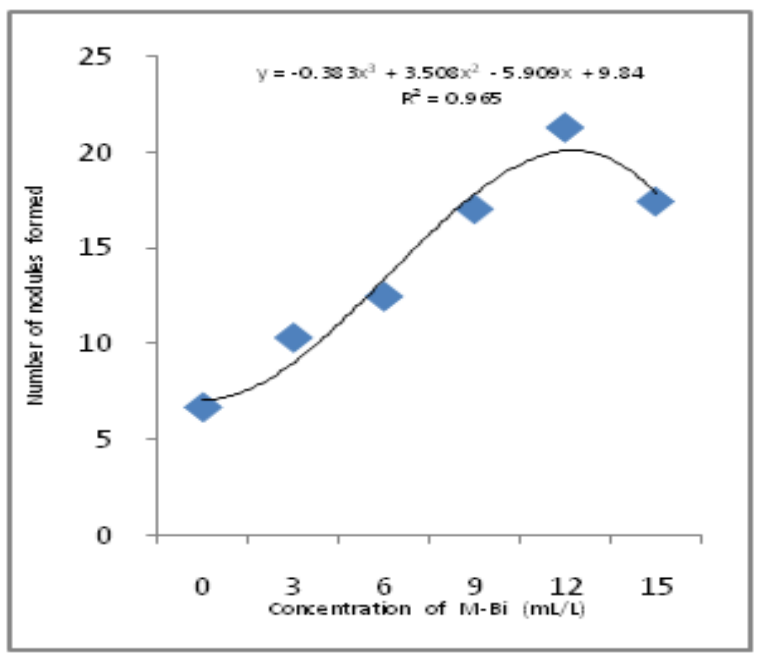

Figure 5 The concentration of M-Bio relationship with number of nodules
Effect of the various concentrations of M-bio fertilizer on plant height, stem diameter and root length are correlated with highly significant $\mathrm{R}$ value in consecutive i.e. plant height $\mathrm{R}=$ 0.959 (Figure 1), stem diameter $\mathrm{R}=0.997$ (Figure 2), and length root $\mathrm{R}=0.945$ (Figure 3).

3.2 Effect of M-bio biofertilizer on various nodules and effective nodules characteristics

Effect of M-bio fertilizer on average nodule diameter, number of nodule and number effective nodules are represented in table 2. Like growth factors, the treatment containing $12 \mathrm{ml}$ per liter of water M-bio provides the highest influence on these parameters while the lowest nodule number, nodule diameter and number of effective nodule was reported from the control. The treatment containing $15 \mathrm{ml}$ per liter of M-bio did not show any significant difference from $9 \mathrm{ml}$ per liter of M-bio and these two treatments are at par to each other. Highest nodule diameter $(5.14 \mathrm{~mm})$, nodule number $(21.47$ pieces $)$ and active nodule ( 16.63 pieces) was reported from the $12 \mathrm{ml}$ per liter of M-bio.

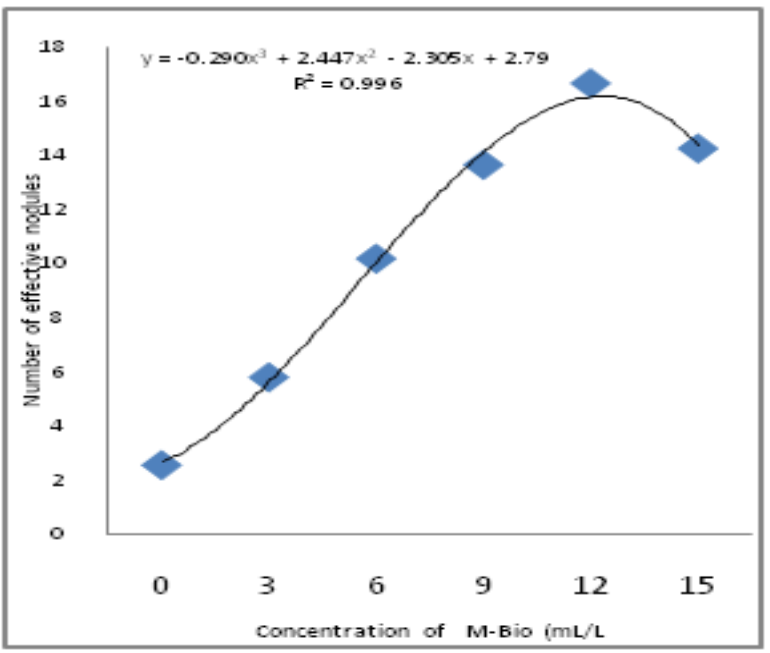

Figure 6 The concentration of M-Bio relationship with number of effective nodules 
Table 3 Effect of M-biofertilizer on the wet and dry weight of nodules, wet and dry weight of effective nodules (g).

\begin{tabular}{|lcccc|}
\hline Treatments & $\begin{array}{c}\text { Wet weight of } \\
\text { nodules }(\mathbf{g})\end{array}$ & $\begin{array}{c}\text { Dry weight of } \\
\text { nodules }(\mathbf{g})\end{array}$ & $\begin{array}{c}\text { Wet weight of } \\
\text { effective } \\
\text { nodules (g) }\end{array}$ & $\begin{array}{c}\text { Dry weight of effective } \\
\text { nodules }(\mathbf{g})\end{array}$ \\
\hline Without M-bio (control) & $0.97 \pm 0.067^{\mathrm{d}}$ & $0.31 \pm 0.012^{\mathrm{d}}$ & $0.80 \pm 0.058^{\mathrm{e}}$ & $0.28 \pm 0.015^{\mathrm{e}}$ \\
M-bio 3 ml per liter of water & $1.57 \pm 0.186^{\mathrm{d}}$ & $0.48 \pm 0.056^{\mathrm{d}}$ & $1.37 \pm 0.067^{\mathrm{d}}$ & $0.41 \pm 0.022^{\mathrm{d}}$ \\
M-bio 6 ml per liter of water & $2.63 \pm 0.145^{\mathrm{c}}$ & $0.80 \pm 0.053^{\mathrm{c}}$ & $2.27 \pm 0.088^{\mathrm{c}}$ & $0.68 \pm 0.026^{\mathrm{c}}$ \\
M-bio 9 ml per liter of water & $4.17 \pm 0.088^{\mathrm{b}}$ & $1.25 \pm 0.026^{\mathrm{b}}$ & $3.73 \pm 0.120^{\mathrm{b}}$ & $1.12 \pm 0.037^{\mathrm{b}}$ \\
M-bio 12 ml per liter of water & $6.80 \pm 0.058^{\mathrm{a}}$ & $2.04 \pm 0.017^{\mathrm{a}}$ & $4.30 \pm 0.058^{\mathrm{a}}$ & $1.29 \pm 0.017^{\mathrm{a}}$ \\
M-bio 15 ml per liter of water & $4.23 \pm 0.176^{\mathrm{b}}$ & $1.27 \pm 0.053^{\mathrm{b}}$ & $3.80 \pm 0.115^{\mathrm{b}}$ & $1.14 \pm 0.032^{\mathrm{b}}$ \\
SEM Value & 0.05 & 0.004 & 0.02 & 0.002 \\
\hline HSDT 95\% & 0.69 & 0.21 & 0.46 & 0.13 \\
\hline
\end{tabular}

Here, SEM = standard error mean, the number followed by the same superscript letters in the same column are not significantly differ on HSDT $95 \%$.

Treatment of various concentrations of M-bio fertilizer on nodule diameter, number of nodules and number of effective nodules correlated highly significant with the $\mathrm{R}$ value in consecutive i.e.nodule diameter $\mathrm{R}=0.990$ (Figure 4), number of nodules $\mathrm{R}=0.965$ (Figure 5), and number of effective nodules $\mathrm{R}=0.996$ (Figure 6).

3.3 Effect of M-bio fertilizer on fresh and dry weight of nodules and effective nodules

A significant effect M-bio fertilizer on average fresh and dry weight of nodules and effective nodules was reported in present study (Table 3 ).

Here also the treatment $12 \mathrm{ml}$ of M-bio shows superiority over the other treatments and found effective in improving fresh weight of nodules $(6.80 \mathrm{~g})$ and effective nodules $(4.30 \mathrm{~g})$.

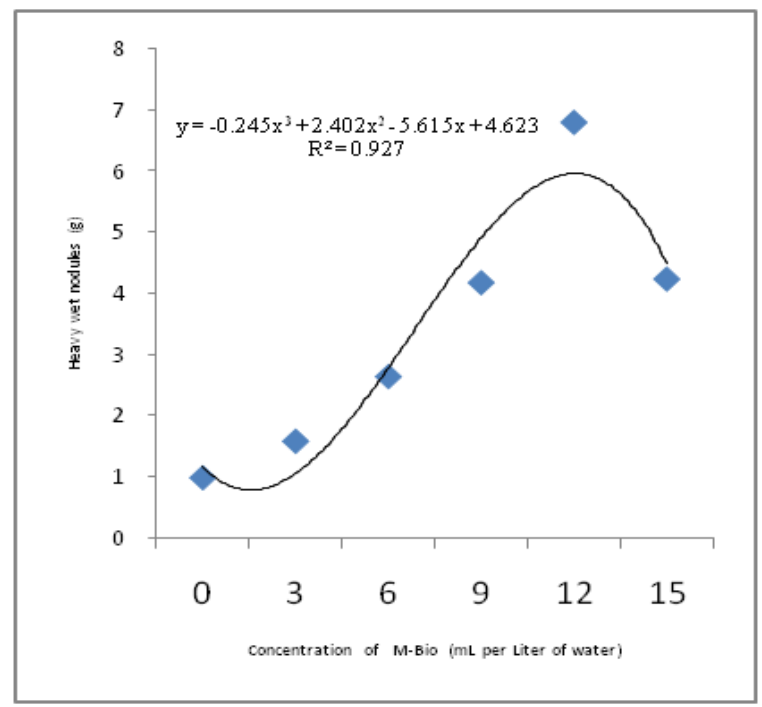

Figure 7 The concentration of M-Bio relationship with heavy wet nodules
Further, same treatments found effective in increasing dry weight of nodules (2.04 pieces) and effective nodules (1.29 pieces). This growth pattern was immediately followed by the treatment $15 \mathrm{ml} \mathrm{M}$-Bio and $9 \mathrm{ml} \mathrm{M}$-Bio and these two treatments are at par to each other and are not significantly different to each others. Among various treatments lowest dose of M-bio (3 ml) is least effective and it is showing similar weight to control.

Various concentrations of M-bio fertilizer are effective in increasing fresh and dry weight of nodules and effective nodules and it is correlated with highly significant $R$ value in consecutive i.e.wet weight of nodules $R=0.927$ (Figure 7), dry weight of nodules $\mathrm{R}=0.926$ (Figure 8), wet weight of effective nodules $\mathrm{R}=0.996$ (Figure 9) and dry weight of effective nodules $\mathrm{R}=0.996$ (Figure 10).

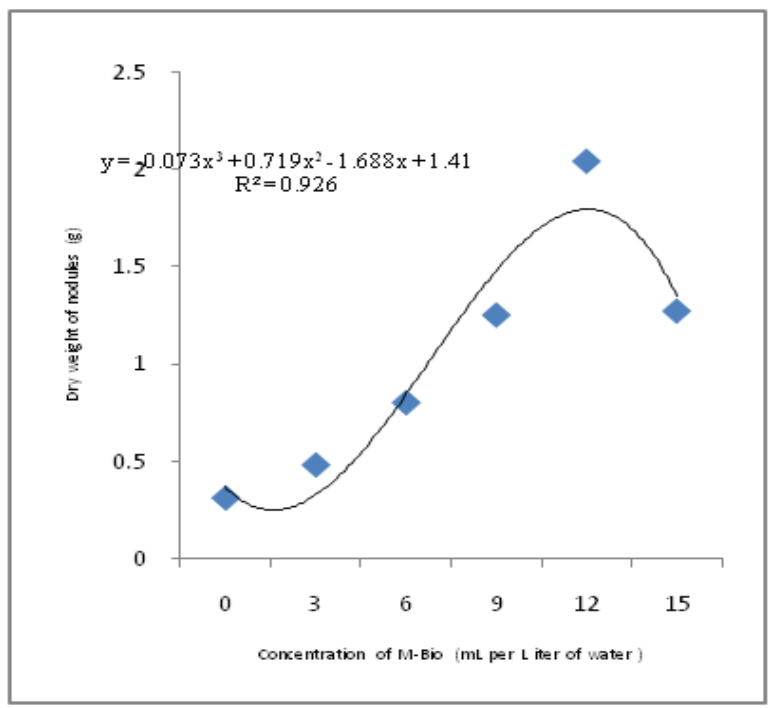

Figure 8 The concentration of M-Bio relationship with dry weight of nodules 


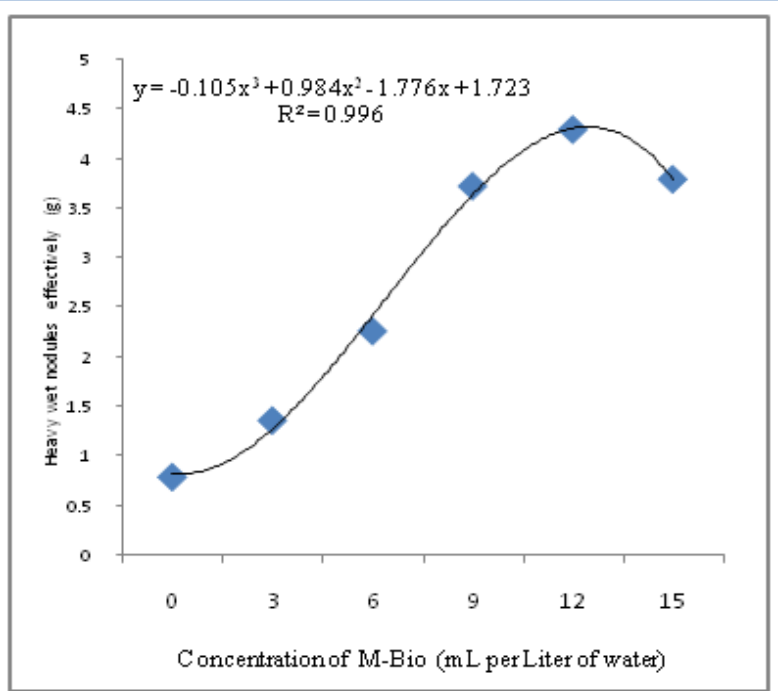

Figure 9 The concentration of M-Bio relationship with plant heavy wet nodules effectively

\section{Discussions}

Application of biological fertilizer (M-bio) on soybean crops is primarily aim to maximize and streamline the process of nitrogen fixation in soybean plants grown in Ultisol conditions. Generally Ultisol contain low organic matter and high bulk density, these conditions are not favorable for the growth of bradyrhizobium. Application of external rhizobium may cause improvement in nitrogen fixation. Therefore, application of Mbio fertilizers containing rhizobium increased the formation of nodules. Use of biological fertilizers as a source of rhizobium in order to improve nitrogen fixation in soybean crop should be more careful, especially on marginal soils (Sarawa, 2014).

According to Remans et al. (2008) plants provides various responses in terms of nitrogen fixation when combination of rhizobium an azospirillum applied to the soybean crops. Results of present study revealed that application of M-bio caused significant improvement in the plant growth characters such as plant height, stem diameter and root length. This improvement was continuous till the concentration reached to $12 \mathrm{ml}$, further improvement in the concentration of M-bio exerts a negative effect on the plant growth characteristics. This improvement in the growth characteristics is because of the presence of nitrogen fixing bacteria in M-bio. Further, the higher nitrogen content spurs the growth of plant height. Results of this study are in agreement with the findings of Misran (2013) those who reported higher plant growth on the application of biological fertilizer. Further, Andrews et al. (2006) reported 6-12\% improvement in soybean plant growth as compared to the control on the application of compost (manure).

The treatment of M-bio $12 \mathrm{ml}$ per liter of water provides a higher impact on stem diameter. The growth of plants stem

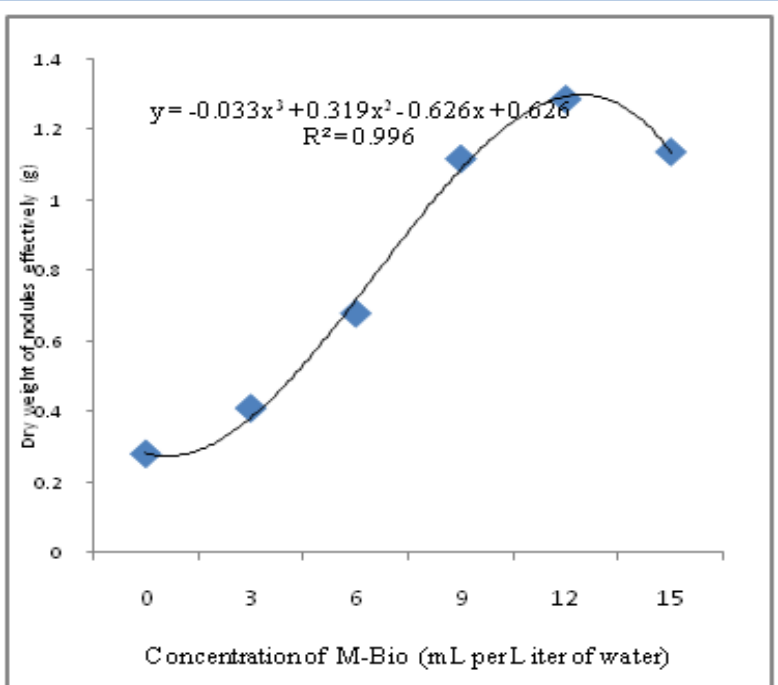

Figure 10 The concentration of M-Bio relationship with plant dry wet nodules effectively

diameter usually concurrent with plants growth. It can be understood because of their dominance of the high growth of plants usually cause a drag on growth aside, including a stem diameter (Sarawa, 2009a; Sarawa, 2009b). Further, Sarawa (2009b) reported a negative correlation between plant height and stem diameter.

The root growth in plants is strongly influenced by genetic and environmental factors. In present study, the root growth pattern is showing similarities with the plant height and stem diameter pattern. At the time of the vegetative phase before the main stream fotosintat used leaves, roots, and nodules. According to Egli (1985) it can be assimilate in the form of starch, mainly in the leaves and other organs. Further, Mayaki (1976) reported that $25 \%-40 \%$ root dry weight reached at the time of vegetative growth. Root growth is generally parallel with the development of shoot and reached maximum shortly after seed filling (Hicks, 1978).

The growth of nodules in response bacterium rhizobium and phosphate stimulates the formation of nodules and it may be because of the synergetic effect of these two. Similar type of findings was reported by Sarawa (2014) when he tried combination of biological fertilizers contain rhizobium bacteria, along with phosphate dissolution bacteria and some microbial decomposers. Generally, biological fertilizer is a mixture of specific microorganisms which are active involved in nitrogen-fixate phosphate dissolution and decomposition of organic material. According to Sarawa (2009b) plants nitrogen, metabolism depended on various factors such as plant species, availability of nitrogen, temperature and some other environmental factors.

Formation of effective nodules those participated in the atmospheric nitrogen fixation is strongly influenced by the 
availability of Molybdenum (Mo). The Mo element is a cofactor for the enzyme nitrogenase (Sarawa, 2014).The nodules are effective in addition to obtaining sufficient supply assimilate of host plants, are also capable of forming a nitrogenase enzyme conversion process fixation of $\mathrm{N}_{2}$ and $\mathrm{NH}_{4} \mathrm{NO}_{3}$. Nitrogen fixation efficiency of a rhizobium strain affect the number and size of the nodule (Provost et al., 2010). Furthermore it is said that increased plant growth generally correlates with the size of the nodule, nodule weight, number and activity of nitrogenase.

M-bio has positive influence on fresh and dry weight of nodules, and effective nodules. Weight of plant is the result of partitioning fotosintat nodules to the roots of soybean plants. If symbiotic rhizobium with soybean plants are effective, optimal plant growth rate and, formation of nodules occurred. Conversely if the soybean plant growth is inhibited and the formation of nodules will also be hampered. Provision of Mbio is able to increase the formation and growth of plants, which in turn increases the weight of nodules, These findings are in agreement with the revelation Sarawa (2011) that reported the effect of nutriflora (liquid fertilizer) to dry weight of plants, tends to increase with increasing concentration of nutriflora given. From the findings of this study it can be conclude that M-bio can enhanced plant growth and nodule formation. A positive correlation was reported between growth characters and M-bio does and highest growth was reported in $12 \mathrm{ml}$ of M-bio.

\section{Acknowledgements}

The author would like to thank to the Ministry of National Education, Republic of Indonesia for the financial assistance through the scheme of Competitive Grants Research. The author also thank to the Rector of Halu Oleo University and the Chairman of the Research Intitute of Halu Oleo University for providing us moral support and space carry out this study.

\section{Conflict of interest}

Authors would hereby like to declare that there is no conflict of interests that could possibly arise.

\section{References}

Andrews MC, Gina M, Liebman M, Cambardella, Cynthia A, Richard TL (2006) Residual effect of composted and fresh solid swine (Susscrofa L.) manure on soybean (Glicine max (L.) growth and yield. Agronomy Journal 98:873-882. DOI:10.3923/pjn.2006.286.293.

Anetor MO, Akinrinde EA (2006) Response of soybean (Glicine max (L.) Merrill) to lime and phosphorus fertilizer treatment on an acid of Nigeria. Pakistan Journal of Nutrition 5:286-293.doi:10.1016/20028-0717(99)00143-1.

Bakere W, Hailemariam A (2012) Influences of Inoculation Methods and Phosphorus Level on Nitrogen Fixation Attribute and Yield of Soybean (Glicine max (L.) Merril) At Haru Western Ethopia. American Journal of Plant Nutrition and Fertilization Technology 2: 45-55.

Barbara S, Ndakidemi PA (2010) The potential roles of lime and molybdenum on the growth, nitrogen fixation and assimilation of metabolites in nodulated legume : A Special reference to Phaseolus vulgaris L. African journal of Biotechnology 8:2482-2489.

Bejiga G (2004) Current Status of foodLegume Production and Use of Biological Nitrogen Fixation in Ethopia. In: Serraj R (Ed.). Symbiotic Nitrogen Fixation Prospect for Enhanced Application in Tropical Agricuture, Oxford and IBH Publishing Co. Pvt. Ltd., New Delhi, India, pp: 263-265.

Egli DB, Guffy RD, Legget JE (1985) Partitioning of assimilate between vegetative and reproductive growth in soybeans. Agronomy Journal 77:917-922.

Ellafi AM, Gadalla A, Galal YGM (2011) Bio-ferlizers in action: Contribution of BNF Sustainable Agricultural Ecosystems. International Science Research Journal 3:108-116.

Handarson M, Golbs, Danso SKA (1989) Nitrogen Fixation in soybean pattern. Soil Biology and Chemistry 21:783-787.

Hicks DR (1978) Growth and Development In: Norman AG (Ed.) Soybeans Physiology, Agronomy and Nutrition, Academic Press, New York, pp 17-44.

Keyser HH, Li F (1992) Potential for increasing biological nitrogen fixation in Soybean. Plant and Soil 141:119-135.

Kris Joko S (2001) Efektivitas Nodulasi Rhizbium japonicum pada Kedalai yang Tumbuh di Tanah Sisa Inokulasi dan tanah dengan Inokulasi Tambahan. Jurnal Ilmu-Ilmu Pertanian Indonesia 3:31-35.

Kundu M, Singh H, Tripathi AK, Manna MC, Takkar PN (1996) Effect of farmyar manure on nitrogen fixation soybean (Glicine max ) and it net potential contribution of $\mathrm{N}$ balance as measured by-N.tracer methodology. Indian Journal of Agricultural Science 66:509-518.

Mayaki WC, Teare ID, Stone LR (1976) Top and root growth of irrigated and nonirrigated soybeans. Crop Science 16:9294.

Misran(2013) Studi Penggunaan Pupuk Hayati Pada Tanaman Kedelai. Journal Penelitian Pertanian Terapan 13 :206-210.

Nurmayulis, Utama P, and Jannah R (2014) growth and yield of lettuce plant (Lactuca sarifa) that were given organic chicken manure plus some bioactivators. Jurnal Agrologia 3:1:44-53. 
Provost D, Bertrand A, Juge C, Chalifor FP (2009) Elevated $\mathrm{CO} 2$ induce differences in, nodulation of soybean depending on brady rhizobial strain and method of inoculation. Plant and Soil 331:115-127.

Remans R, Remaekers L, Schalkens S, Hernandez G, Gercia A, Luis RJ, Mendez N, Toscano V, Mulling M, Galves L, Vanderleyden J (2008) Effect of Rhizobium-Azospirillum coinculation on nitrogen fixation and yield of two contrasting Phaseolus vulgaris L. Genotypes cultivated across differentenvironments in Cuba. Plant Soil 312:25-37.

Sanginga N, Thottappilly G, Dashill K (2000) Effectiveness of rhizobia nodulation recent promiscuous soybean selection in the most savanna of Nigeria. Soil Biology and Biochemistry 32:127-133.

Sarawa (2009a) Fisiologi Tumbuhan, Pendekatan Praktis. Unhalu Press.Kendari.
Sarawa (2009b) Pengaruh pemberian pupuk urea-nitrofoska terhadap pertumbuhan dan hasil tanaman tomat pada berbagai medium tanaman dengan sistem hidroponik. Jurnal Agrivigor 8:177-186.

Sarawa (2011) Perkecambahan dan pertumbuhan tanaman sawi (Brassica juncea L.) yang diberi pupuk cair nutrifloradengan sistem hidroponik. Jurnal Agroteknos 1:82-88.

Sarawa (2014) Pertanian organik pada lahan sub optimal. Unhalu Press. Kendari.

Singh M, Kundu S, Biswas AK, Saha JK, Tripathi AK, Acharya CL (2004) Quantification of N2 fixation and annual N benefit from $\mathrm{N} 2$ fixation in soybean accrued to the soil under soybean-wheat continuous rotation. Journal of Plant Nutrition of Indian Society of Soil Science 167:577-583. DOI:583101002/jpln.200220892. 